\title{
PREDIKSI RETURN SAHAM PADA PERUSAHAAN SEKTOR PERTAMBANGAN YANG TERDAFTAR DI BURSA EFEK INDONESIA
}

\section{PREDICTION ANALYSIS OF RETURN OF SHARES IN MINING SECTOR COMPANIES LISTED IN INDONESIA STOCK EXCHANGE}

\author{
A. Lasmana, L. Ashariah \\ Program Studi Akuntansi Fakultas Ekonomi Universitas Djuanda Bogor \\ Jl. Tol Ciawi No.1, Kotak Pos 35, Kode Pos 16720. Telp/Fax: (0251) 8245155 \\ E-mail: : andy.lasmana@unida.ac, ashariahleni@gmail.com
}

\begin{abstract}
Investors in the capital market has many options to invest, so it has a different risk preferences. This study aimed to determine the effect of stock return one and two years to come to the mining industry listed in Indonesia Stock Exchange (BEI), and to determine the financial ratios anything that can distinguish the tendency of the two groups that have a positive return and a negative return on mining industry sectors listed on the Indonesia Stock Exchange (BEI). The population in this study is the mining industry listed in Indonesia Stock Exchange (BEI), which consists of 43 companies. Sampling totaling 29 mining companies conducted by purposive sampling. Data analysis using Multiple Discriminant Analysis. The results showedthat a significant difference between companies that have positive returns and negative returns in the period (t-2) is variableCurrent Assets to Total Assets, Operating Profit Margin, Return on Equity, dividend and Yield, While on the one-year period prior to the return (t-1), a significant difference is the Gross Profit Margin, EBIT to Total Assets, Yield, Current Assets to Sales. With the MDA models have an accuracy rate of $82.2 \%$ in the period $(t-2)$ and $79.3 \%$ for the period $(t-1)$.
\end{abstract}

Keywords: Prediction, Stock Return, Financial Ratios, MDA

\begin{abstract}
ABSTRAK
Investor di pasar modal memiliki banyak pilihan berinvestasi, sehingga memiliki preferensi resiko yang berbeda. Penelitian ini bertujuan untuk mengetahui pengaruh return saham satu dan dua tahun yang akan datang pada sektor industri pertambangan yang terdaftar di Bursa Efek Indonesia (BEI), dan untuk mengetahui rasio keuangan apa saja yang dapat membedakan kecenderungan kedua kelompok yang memiliki return positif dan return negatif pada sektor industri pertambangan yang terdaftar di Bursa Efek Indonesia (BEI). Populasi dalam penelitian ini adalah industri pertambangan yang terdaftar di Bursa Efek Indonesia (BEI) yang terdiri dari 43 perusahaan. Pengambilan sampel yang berjumlah 29 perusahaan pertambangan dilakukan dengan purposive sampling. Analisis data menggunakan Multiple Discriminant Analysis. Hasil penelitian menunjukan bahwa signifikan perbedaannya di antara perusahaan yang memiliki return positif dan return negatif pada periode (t-2) adalah variabel Current Assets to Total Assets, Operating Profit Margin, Return on Equity, Devidend dan Yield. Sedangkan pada periode satu tahun sebelum return (t-1), signifikan perbedaannya adalah Gross Profit Margin, EBIT to Total Assets, Yield, Current Assets to Sales. Dengan model MDA memiliki tingkat akurasi 82,2\% pada periode (t-2) dan 79,3\% untuk periode (t-1).
\end{abstract}

Kata kunci : Prediksi, Return Saham,Rasio Keuangan, MDA 


\section{PENDAHULUAN}

Keberadaan pasar modal, investor memiliki banyak pilihan untuk berinvestasi, salah satunya investasi dalam financial asset yang memiliki preferensi risiko yang berbeda. Investor dalam menanamkan modalnya memiliki tujuan yang diharapkan berupa return. Return dapat dibagi menjadi dua, yaitu devidend dan capital gain. Ada investor yang ingin mendapatkan keuntungan dalam waktu jangka panjang dengan memperoleh devidend, sehingga para investor tersebut tidak terlalu menghiraukan perubahan fluktuasi yang ada dipasar modal melainkan hanya melihat laporan keuangan yang ada pada perusahaan tersebut. Namun ada pula investor yang menginginkan keuntungan dalam jangka pendek yang dapat diperoleh dengan mendapatkan capital gain atau Return saham yang merupakan kelebihan harga jual saham diatas harga belinya, yang umumnya dinyatakan dalam persentase terhadap harga beli. Semakin tinggi harga jual saham di atas harga belinya, maka semakin tinggi pula return yang diperoleh investor.

Individu yang rasional, investor akan mempertimbangkan return yang diharapkan akan diterima (expected return) dan besaran risiko yang harus ditanggung sebagai konsekuensi logis dari keputusan yang telah diambil. Apabila seseorang investor menginginkan return yang tinggi maka ia harus bersedia menanggung risiko lebih tinggi, demikian pula sebaliknya. Mengingat pentingnya harga saham dalam menentukan besarnya return saham yang mungkin diterima investor maka dinamika perubahan harga saham atau return saham merupakan hal yang menarik untuk dikaji (Ang, 1997)

Industri pertambangan merupakan salah satu sektor industry yang memiliki resiko paling besar dibanding sektor lainnya karena pada sektor pertambangan modal yang dibutuhkan relatif cukup besar dan tingkat pengembalian yang membutuhkan waktu yang lama. Hal ini diperjelas dengan terpuruknya sektor pertambangan pada tahun 2015
Keterpurukan pada sektor pertambangan tersebut membuat adanya kekhawatiran terkait dengan soft mentality yang ditunjukan pemengang saham dengan hanya fokus pada fluktuasi harga komoditas dan imbal jangka pendek dari pada sudut pandang investasi jangka panjang pada sektor pertambangan. Naik turunnya kapitalisasi pasar pertambangan mempengaruhi harga saham sektor pentambangan yang terus menurun hingga banyaknya perusahaan pertambangan yang mengalami capital loss yang dapat dijelaskan gambar berikut:

\section{Return Saham Perusahaan Pertambangan yang Terdaftar di Bursa Efek Indonesia Tahun 2015-2017}

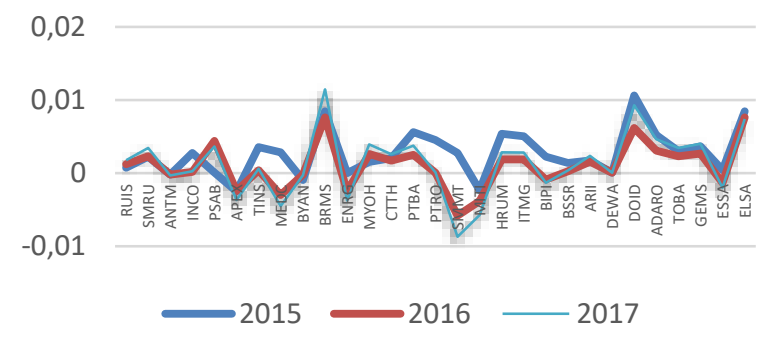

Sumber : www.finance.yahoo.com (data diolah 2018)

Gambar 1.1 Return Saham Perusahaan Pertambangan yang Terdaftar di BEI 20152017

Gambar 1.1 bahwa banyaknya perusahaan pertambangan yang mengalami return saham negatif (capital loss) selama periode penelitian. Penurunan return saham yang sangat tajam terjadi pada PT Golden Eagle Energy Tbk. (SMMT) dilihat dari laporan keuangan tahun 2015 dan 2016 PT Golden Eagle Energy Tbk mengalami likuiditas yang kurang baik yaitu dilihat cash to sales sebesar 3,75 dan 0,28 hal tersebut diakibatkan oleh lebih banyaknya cash (uang menganggur) dibandingkan dengan penjualan, sedangkan perusahaan yang memiliki return saham yang tinggi selama periode penelitian adalah PT Delta Dunia Makmur, Tbk (DOID) jika dibandingkan dengan PT Golden Eagle 
Energy Tbk cash to sales PT Delta Dunia Makmur, Tbk memiliki selisih yang cukup besar dimana cash to sales pada PT Golden Eagle Energy Tbk sebesar 0,125 dan 0,11.

Kondisi tersebut sedikitnya disebabkan oleh menurunnya permintaan dari Tiongkok dan negara-negara berkembang lainnya menyebabkan penurunan signifikan atas kinerja keuangan perusahaan. Keterpurukan pada sektor pertambangan tersebut membuat adanya kekhawatiran terkait dengan soft mentality yang ditunjukan pemengang saham dengan hanya fokus pada fluktuasi harga komoditas dan imbal jangka pendek dari pada sudut pandang investasi jangka panjang pada sektor pertambangan. Hal tersebut berdampak pada keterbatasan modal untuk diinvestasikan dan mengakibatkan terbatasnya opsi untuk pertumbuhan.

Penelitian ini, return digunakan pada suatu investasi untuk mengukur hasil keuangan suatu perusahaan. Laporan keuangan merupakan alat yang sangat penting untuk memperoleh informasi sehubungan dengan posisi keuangan dan hasil yang telah dicapai oleh perusahaan (Munawir, 2010:31). Menganalisis kinerja keuangan yang dimiliki perusahaan biasanya para investor menerapkan konsep "think fast and decision fast”. Karena faktor tersebut para investor menggunakan rasio keuangan yang dianggap lebih fleksibel dan sederhana namun dapat memberikan jawaban yang mereka inginkan. Laporan keuangan merupakan sebuah informasi yang penting bagi investor dalam mengambil keputusan investasi. Manfaat laporan keuangan tersebut menjadi optimal bagi investor apabila investor dapat menganalisis lebih lanjut melalui analisi rasio.

Menurut penelitian yang dilakukan Allozi dan Obeidat (2016) Hasil penelitian ini menunjukkan bahwa empat dari rasio keuangan memiliki hubungan yang signifikan dengan return saham yaitu: EPS, ROE, ROA dan GPM. Hasil penelitian yang dilakukan oleh Öztürk dan Karabulut (2017) menunjukan earning ratio dan profit margin memiliki hubungan yang signifikan positif dengan return saham. penelitian yang dilakukan Hubbansyah (2013) mengungkapkan pada periode dua tahun sebelum bangkrut (t-2) diketahui dari model $M D A$ bahwa variabel SEQ, GPM, WCTA, WCS dan RETA sangat signifikan di dalam membedakan kedua kelompok dan pada periode satu tahun sebelum bangkrut (t-1), berdasarkan model MDA diketahui ada empat variabel yang signifikan perbedaannya di antara perusahaan bangkrut dan tidak bangkrut. Keempat variabel tersebut adalah RETA, NITA, GPM dan CS.

\section{METODE PENELITIAN}

Penelitian ini menggunakan data rasio keuangan tahun 2015-2016 dan return saham penutupan harian yang dikomulatifkan pada sektor industri pertambangan yang terdaftar di Bursa Efek Indonesia (BEI). Jumlah perusahaan yang terdaftar di Bursa Efek Indonesia yang termasuk dalam industri ini sebanyak 43 perusahaan dan pemiliham sampel menggunakan purposive sampling sehingga diperoleh 29 perusahaan sebagai sampel penelitian,

Berdasarkan metodenya, penelitian ini dilakukan dengan pendekatan exsperimen, dimana penelitian ini berusaha mencari variabel yang dapat membedakan antara return positif dan return negatif pada satu dan dua tahun yang akan datang.

\section{VARIABEL PENELITIAN}

Variabel independen (X) atau variabel bebas dalam penelitian ini adalah 32 rasio keuangan sebagai berkut : 


\begin{tabular}{|c|c|}
\hline Nama & Definisi \\
\hline Rasio Likuiditas $\left(\mathrm{X}_{1}\right)$ & $\begin{array}{l}\text { - Current Ratio } \\
\text { - Quick Ratio } \\
\text { - Cash Ratio } \\
\text { - Cash to Total Assets } \\
\text { - Working Capital to Total Assets } \\
\text { - Cash to Sales } \\
\text { - Current Assets to Total Aseet } \\
\text { - Current Liabilities Ratio } \\
\text { - Inventory Current Assets }\end{array}$ \\
\hline Rasio Leverage $\left(\mathrm{X}_{2}\right)$ & $\begin{array}{l}\text { - Debt to Total Assets Ratio } \\
\text { - Debt to Equity Ratio } \\
\text { - Financial Leverage Multiplier } \\
\text { - Fixed Asset to Equity \& Long Term Liabilities }\end{array}$ \\
\hline Rasio Profitabilitas $\left(\mathrm{X}_{3}\right)$ & $\begin{array}{l}\text { - Gross Profit Margin } \\
\text { - Operating Profit Margin } \\
\text { - Net Profit Margin } \\
\text { - Return on Assets } \\
\text { - Return on Equity } \\
\text { - EBIT to Total Assets }\end{array}$ \\
\hline Rasio Pasar $\left(\mathrm{X}_{4}\right)$ & $\begin{array}{l}\text { - Earning Per Share } \\
\text { - Price Earning Ratio } \\
\text { - Devidend } \\
\text { - Yield } \\
\text { - Price to Book Value } \\
\text { - Book Value }\end{array}$ \\
\hline Rasio Aktivitas $\left(\mathrm{X}_{5}\right)$ & $\begin{array}{l}\text { - Fixed Asset Turnover } \\
\text { - Total Asset Turnover } \\
\text { - Equity Turnover } \\
\text { - Inventory to Sales } \\
\text { - Receivables Turnover } \\
\text { - Quick Assets to Sales } \\
\text { - Current Assets to Sales }\end{array}$ \\
\hline
\end{tabular}

Variabel dependen (Y) variabel terikat yang digunakan dalam penelitian ini adalah return saham komulatif tahun 2017

Return $=\left(\mathrm{P}_{\mathrm{t}}-\mathrm{P}_{\mathrm{t}-1}\right) / \mathrm{P}_{\mathrm{t}-1}$

\section{HASIL DAN PEMBAHASAN}

\subsubsection{MDA Periode Dua Tahun Sebelum Return Saham}

Pendekatan Multiple Discriminant Analysis (MDA) mencoba untuk meramalkan group membership, karena itu harus diuji dahulu apakah terdapat perbedaan signifikan 
variabel independen (predictor) di antara kedua kelompok (group) dengan menggunakan data group means dan ANOVA.

Jika tidak ditemukan perbedaan yang signifikan di antara variabel independen kedua kelompok, maka proses discriminant analysis dihentikan. Informasi ada tidaknya perbedaan itu, dapat dilihat melalui tabel Test of Equality of Group Means.

Tabel 4.12

Test of Equality of Group Means.

\begin{tabular}{lrrrrr}
\hline \multicolumn{1}{|c}{ VAR } & $\begin{array}{r}\text { Wilks' } \\
\text { Lambda }\end{array}$ & \multicolumn{1}{c}{$\mathrm{F}$} & $\mathrm{df} 1$ & \multicolumn{1}{c}{$\begin{array}{c}\text { df } \\
\text { Sig. }\end{array}$} \\
\hline Current Ratio & 0,935 & 1,885 & 1 & 27 & 0,181 \\
\hline Quick Ratio & 0,946 & 1,542 & 1 & 27 & 0,225 \\
\hline Cash Ratio & 1 & 0,001 & 1 & 27 & 0,977 \\
\hline Cash to Total Assets & 0,983 & 0,471 & 1 & 27 & 0,498 \\
\hline Working Capital to Total Assets & 0,999 & 0,04 & 1 & 27 & 0,843 \\
\hline Cash to Sales & 0,945 & 1,574 & 1 & 27 & 0,22 \\
\hline Current Assets to Total Assets & 0,937 & 1,818 & 1 & 27 & 0,189 \\
\hline Current Liabilities Ratio & 0,991 & 0,246 & 1 & 27 & 0,624 \\
\hline Inventory Current Assets & 0,974 & 0,716 & 1 & 27 & 0,405 \\
\hline Debt to Total Assets Ratio & 0,97 & 0,834 & 1 & 27 & 0,369 \\
\hline Debt to Equity Ratio & 0,984 & 0,451 & 1 & 27 & 0,507 \\
\hline Financial Leverage Multiplier & 1 & 0,004 & 1 & 27 & 0,948 \\
\hline Fixed Asset to Equity \& Long Term & 0,949 & 1,456 & 1 & 27 & 0,238 \\
Liabilities & 0,98 & 0,55 & 1 & 27 & 0,465 \\
\hline Gross Profit Margin & 0,966 & 0,948 & 1 & 27 & 0,339 \\
\hline Operating Profit Margin & 0,963 & 1,052 & 1 & 27 & 0,314 \\
\hline Net Profit Margin & 0,924 & 2,217 & 1 & 27 & 0,148 \\
\hline Return on Assets & 0,9 & 3,009 & 1 & 27 & 0,094 \\
\hline Return on Equity & 0,987 & 0,359 & 1 & 27 & 0,554 \\
\hline EBIT to Total Assets & 0,875 & 3,856 & 1 & 27 & 0,06 \\
\hline Earning Per Share & 0,974 & 0,712 & 1 & 27 & 0,406 \\
\hline Price Earning Ratio & 0,92 & 2,356 & 1 & 27 & 0,136 \\
\hline Devidend & 0,838 & 5,207 & 1 & 27 & 0,031 \\
\hline Yield & 0,949 & 1,465 & 1 & 27 & 0,237 \\
\hline Price to Book Value & 0,936 & 1,854 & 1 & 27 & 0,185 \\
\hline Book Value & 0,978 & 0,606 & 1 & 27 & 0,443 \\
\hline Fixed Asset Turnover & 0,861 & 4,363 & 1 & 27 & 0,046 \\
\hline Total Asset Turnover & 0,916 & 2,46 & 1 & 27 & 0,128 \\
\hline Equity Turnover & 0,975 & 0,692 & 1 & 27 & 0.41 \\
\hline Inventory to Sales & 0,995 & 0,137 & 1 & 27 & 0,715 \\
\hline Receivables Turnover & 0,964 & 0,997 & 1 & 27 & 0,327 \\
\hline Quick Assets to Sales & 0,993 & 0,199 & 1 & 27 & 0,659 \\
\hline Current Assets to Sales & & & & & \\
\hline & & &
\end{tabular}


Tabel di atas merupakan hasil pengujian variabel bebas yang ada. Interpretasi atas hasil keluaran (output) Test of Equality of Group
Means dapat dilakukan melalui dua cara, yaitu :

1. Wilk's Lambda:

2. F Test

Tabel 4.13

Eigenvalues

\begin{tabular}{ccccc}
\hline Function & Eigenvalue & $\%$ of Var & $\%$ Cumm & Can.Cor \\
\hline 1 &, $781^{\mathrm{a}}$ & 100,0 & 100,0 &, 662 \\
\hline
\end{tabular}

Selanjutnya melalui tabel Wilks Lambda, dapat diketahui besaran variabilitas yang tidak dapat dijelaskan oleh model. Wilk's, untuk setiap prediktor, merupakan rasio dari within group sum of squares dengan total sum of squares, yang nilainya antara 0 dan 1 .

Tabel 4.14

Wilks' Lambda

\begin{tabular}{ccccc}
\hline \multicolumn{5}{c}{ Wilks' Lambda } \\
\hline Function & Wilks' Lambda & Chi-square & Df & Sig. \\
\hline 1 &, 561 & 14,142 & 5 &, 015 \\
\hline
\end{tabular}

Melalui nilai wilk's lambda diketahui persentase variabilitas yang tak dapat dijelaskan oleh variabel independen penelitian adalah sebesar $56.1 \%$ (0.561). Kemudian dari table Standardized Canonical Discriminant
Function diketahui tingkat signifikansi relatif variabel yang masuk kedalam model diskriminan periode dua tahun sebelum Return saham.

Tabel 4.15

Standardized Canonical Discriminant Function Coefficients

\begin{tabular}{cc}
\hline VAR & Function \\
\cline { 2 - 2 } & 1 \\
\hline Current Assets to Total Assets &, 602 \\
\hline Operating Profit Margin &,- 580 \\
\hline Return on Equity &, 617 \\
\hline Devidend & $-1,136$ \\
\hline Yield & 1,704 \\
\hline
\end{tabular}

Variabel yang ada di dalam persamaan model (Current Assets to Total Assets, Operating Profit Margin, Return on Equity, Devidend dan Yield), dari tabel di atas, maka dapat dihasilkan persamaan model diskriminan untuk peramalan return saham periode $\mathrm{t}-2$, sebagai berikut :
$\mathrm{D}=0.602 \mathrm{CATA}-0.580 \mathrm{OPM}+0.617 \mathrm{ROE}-$ 1.136DV+1.704YL
Selanjutnya adalah menentukan cut-off point dari model diskriminan yang telah didapatkan di atas. Group centroid dari kedua kelompok tersebut ditunjukkan melalui tabel di bawah ini. 


\section{Tabel 4.16}

Group Centroids

\begin{tabular}{lr}
\hline \multirow{2}{*}{ Kelompok Perusahaan } & \multicolumn{2}{c}{ Function } \\
\cline { 2 - 2 } & \multicolumn{1}{c}{1} \\
\hline Dibawah Komulatif Industri &,- 769 \\
\hline Diatas Komulatif Industri &, 946 \\
\hline
\end{tabular}

Group Centroids di atas dapat dinyatakan perusahaan dengan nilai diskriminan lebih kecil atau mendekati angka -0,769 akan dikelompokkan kedalam perusahaan yang memiliki return dibawah komulatif industri sebaliknya apabila nilai diskriminannya lebih besar atau mendekati angka 0,946 dapat dikelompokkan kedalam perusahaan yang memiliki return diatas komulatif industri.

$$
\text { Untuk memudahkan proses }
$$

pengelompokkan perusahaan beberapa penelitian membuat suatu optimum cutting score sebagai berikut :

$$
\begin{gathered}
Z_{c v}=\frac{16(-0.769)+13(0.946)}{29} \\
=-0.0002
\end{gathered}
$$

Cutting score kedua kelompok adalah -0.0002 . Hal ini berarti perusahaan dengan nilai diskriminan lebih rendah dari nilai cutting score dikelompokkan sebagai perusahaan return negatif dan sebaliknya.

Tabel 4.17

Classification Result

\begin{tabular}{ccccc}
\hline & $\begin{array}{c}\text { Number } \\
\text { Correct }\end{array}$ & $\begin{array}{c}\text { Precent } \\
\text { Correct }\end{array}$ & $\begin{array}{c}\text { Precent } \\
\text { Error }\end{array}$ & $\mathrm{N}$ \\
\hline Non-failed & 15 & $93.80 \%$ & $6.20 \%$ & 16 \\
\hline Failed & 4 & $30.80 \%$ & $69.20 \%$ & 13 \\
\hline \multicolumn{5}{c}{$82.80 \%$} \\
\hline
\end{tabular}

Dari hasil uji klasifikasi pada origin cases dapat diketahui bahwa model diskriminan periode dua tahun sebelum return ( $\mathrm{t}-2)$ memiliki tingkat akurasi rata-rata sebesar $82.8 \%$.

1.1.2 MDA Periode Satu Tahun Sebelum Return Saham

Tabel 4.18

Classification Result

\begin{tabular}{lrrrrr}
\hline \multicolumn{1}{c}{ VAR } & $\begin{array}{c}\text { Wilks' } \\
\text { Lambda }\end{array}$ & F & df1 & df2 & Sig. \\
\hline Current Ratio & 0,952 & 1,35 & 1 & 27 & 0,255 \\
\hline Quick Ratio & 0,975 & 0,706 & 1 & 27 & 0,408 \\
\hline Cash Ratio & 1 & 0,001 & 1 & 27 & 0,974 \\
\hline Cash to Total Assets & 0,946 & 1,533 & 1 & 27 & 0,226 \\
\hline Working Capital to Total Assets & 0,967 & 0,916 & 1 & 27 & 0,347 \\
\hline Cash to Sales & 0,973 & 0,74 & 1 & 27 & 0,397 \\
\hline Current Assets to Total Assets & 0,95 & 1,424 & 1 & 27 & 0,243 \\
\hline Current Liabilities Ratio & 0,969 & 0,85 & 1 & 27 & 0,365 \\
\hline
\end{tabular}




\begin{tabular}{lrrrrr} 
Inventory Current Assets & 0,972 & 0,788 & 1 & 27 & 0,382 \\
\hline Debt to Total Assets Ratio & 0,983 & 0,456 & 1 & 27 & 0,505 \\
\hline Debt to Equity Ratio & 0,966 & 0,936 & 1 & 27 & 0,342 \\
\hline Financial Leverage Multiplier & 0,99 & 0,282 & 1 & 27 & 0,6 \\
\hline $\begin{array}{l}\text { Fixed Asset to Equity \& Long Term } \\
\text { Liabilities }\end{array}$ & 0,967 & 0,912 & 1 & 27 & 0,348 \\
\hline Gross Profit Margin & 0,956 & 1,232 & 1 & 27 & 0,277 \\
\hline Operating Profit Margin & 0,971 & 0,81 & 1 & 27 & 0,376 \\
\hline Net Profit Margin & 0,972 & 0,788 & 1 & 27 & 0,382 \\
\hline Return on Assets & 0,926 & 2,159 & 1 & 27 & 0,153 \\
\hline Return on Equity & 0,882 & 3,612 & 1 & 27 & 0,068 \\
\hline EBIT to Total Assets & 0,836 & 5,3 & 1 & 27 & 0,029 \\
\hline Earning Per Share & 0,969 & 0,869 & 1 & 27 & 0,36 \\
\hline Price Earning Ratio & 0,982 & 0,508 & 1 & 27 & 0,482 \\
\hline Devidend & 0,944 & 1,598 & 1 & 27 & 0,217 \\
\hline Yield & 0,881 & 3,64 & 1 & 27 & 0,067 \\
\hline Price to Book Value & 0,957 & 1,199 & 1 & 27 & 0,283 \\
\hline Book Value & 0,997 & 0,083 & 1 & 27 & 0,775 \\
\hline Fixed Asset Turnover & 0,979 & 0,566 & 1 & 27 & 0,459 \\
\hline Total Asset Turnover & 0,865 & 4,223 & 1 & 27 & 0,05 \\
\hline Equity Turnover & 0,896 & 3,149 & 1 & 27 & 0,087 \\
\hline Inventory to Sales & 0,95 & 1,429 & 1 & 27 & 0,242 \\
\hline Receivables Turnover & 0,961 & 1,092 & 1 & 27 & 0,305 \\
\hline Quick Assets to Sales & 0,941 & 1,692 & 1 & 27 & 0,204 \\
\hline Current Assets to Sales & 0,949 & 1,466 & 1 & 27 & 0,236 \\
\hline
\end{tabular}

Hasil interpretasi Wilk's Lambda diketahui variabel independen yang perbedaannya signifikan di antara kedua kelompok (Wilk's Lambda < 0.922) adalah Return on Equity, EBIT to Total Assets, Yield, Total Assets Turnover dan Equity Turnover.
Dari hasil uji Test of Equality of Group Means didapatkan beberapa variabel independen yang berbeda secara signifikan di antara kedua kelompok, yang artinya proses analysis discriminant bisa terus dilanjutkan.

Tabel 4.19

\section{Eigenvalues}

\begin{tabular}{crrrr}
\hline \multicolumn{5}{c}{ Eigenvalues } \\
\hline \multirow{2}{*}{ Function } & Eigenvalue & \% of Var & $\%$ Cumm & Can. Cor \\
\hline 1 &, $556^{\mathrm{a}}$ & 100,0 & 100,0 &, 598 \\
\hline
\end{tabular}


Tabel 4.19 Eigenvalues diketahui bahwa model diskriminan periode $\mathrm{t}-1$ ini memiliki nilai eigenvalues yang baik (eigenvalues > 0,3), yakni 0,556 dengan nilai canonical correlation nya adalah 0.598 . angkanya mengalami penurunan sebesar $\pm 8 \%$ dibandingkan periode sebelumnya.

Tabel 4.20

Wilks' lambda

\begin{tabular}{ccccc}
\hline \multicolumn{4}{c}{ Wilks' Lambda } \\
\hline \multirow{2}{*}{ Function } & Wilks' Lambda & $\begin{array}{c}\text { Chi- } \\
\text { square }\end{array}$ & df & Sig. \\
\hline 1 &, 642 & 11,060 & 4 &, 026 \\
\hline
\end{tabular}

Tabel 4. 21 Wilk's Lambda menunjukkan angka yang signifikan pada model diskriminan periode $\mathrm{t}-2$ dengan $p$ sebesar 0.026. Melalui tabel Wilk's Lambda di atas juga diketahui bahwa proporsi dari total variabilitas yang tidak dapat dijelaskan sebesar 0.642 atau 64.2\%. Model yang dihasilkan untuk periode $\mathrm{t}-2$ lebih besar $8.1 \%$ dibandingkan dengan periode $\mathrm{t}-1$.

Tabel 4.21

Standardized Canonical Discriminant Function Coefficients

\begin{tabular}{cc}
\hline VAR & Function \\
\cline { 2 - 2 } & 1 \\
\hline Gross Profit Margin & $-0,469$ \\
\hline EBIT to Total Assets & 0,727 \\
\hline Yield & 0,536 \\
\hline Current Assets to Sales & 0,545 \\
\hline
\end{tabular}

Di antara empat variabel (Gross Profit Margin, EBIT to Total Assets, Yield, Current Assets to Sales) yang ada di dalam persamaan model, EBIT to Total Assets merupakan variabel dengan tingkat signifikansi relatif tertinggi dibanding dengan variabel independen lainnya dengan nilai standar kanonikal sebesar 0.727. sehingga memiliki nilai koefesien yang besar sehingga mampu memprediksi secara akurat kecenderungan perusahaan (return positif dan return negatif). Dari tabel di atas, maka dapat dihasilkan persamaan model diskriminan untuk peramalan return saham periode $\mathrm{t}-1$, sebagai berikut:

$\mathrm{D}=0,469 \mathrm{GPM}+0,727 \mathrm{EBITA}+0,536 \mathrm{YL}+0,54$ 5CAS

Tabel 4.22

Group Centroids

\begin{tabular}{lr}
\hline \multirow{2}{*}{ Kelompok Perusahaan } & \multicolumn{1}{c}{ Function } \\
\cline { 2 - 2 } & \multicolumn{1}{c}{1} \\
\hline Dibawah Komulatif Industri &,- 649 \\
\hline Diatas Komulatif Industri &, 798 \\
\hline
\end{tabular}


Hasil group Centroids di atas dapat dinyatakan perusahaan dengan nilai diskriminan lebih kecil atau mendekati angka -0,649 akan dikelompokkan kedalam perusahaan yang memiliki return dibawah komulatif industri sebaliknya apabila nilai diskriminannya lebih besar atau mendekati angka 0,798 dapat dikelompokkan kedalam perusahaan yang memiliki return diatas komulatif industri. Tetapi, untuk memudahkan proses pengelompokkan perusahaan beberapa penelitian membuat suatu optimum cutting score. Oleh karena penelitian ini mempunyai jumlah sampel perusahaan yang memiliki return negatif dan yang memiliki return positif tidak sama, maka penentuan cutting score nya dihitung dengan menggunakan "rumus kelompok yang tidak proporsional", sebagai berikut :

$$
\begin{gathered}
Z_{c v}=\frac{16(-0.649)+13(0.798)}{29} \\
=-0.0003
\end{gathered}
$$

Perhitungan diatas dapat diartikan apabila bagi perusahaan yang memiliki nilai determinan lebih kecil dari angka nol dapat dinyatakan sebagai perusahan yang memiliki return saham dibawah komulatif industri, dan begitupula sebaliknya.

Tabel 4.23

Classification Result

\begin{tabular}{ccccc}
\hline & $\begin{array}{c}\text { Number } \\
\text { Correct }\end{array}$ & $\begin{array}{c}\text { Precent } \\
\text { Correct }\end{array}$ & $\begin{array}{c}\text { Precent } \\
\text { Error }\end{array}$ & $\mathrm{N}$ \\
\hline Non-failed & 14 & $87.5 \%$ & $12.5 \%$ & 16 \\
\hline Failed & 4 & $30.8 \%$ & $69.2 \%$ & 13 \\
\hline & $79.3 \%$ & & \\
\hline
\end{tabular}

Dari hasil uji klasifikasi pada origin cases dapat diketahui bahwa model diskriminan periode satu tahun sebelum return (t-1) memiliki tingkat akurasi rata-rata sebesar $79.3 \%$.

\section{PEMBAHASAN HASIL PENELITIAN}

1. Dari hasil uji Test of Equality of Group Means. Ho ditolak dan $\mathrm{Ha}$ diterima karena dilihat dari tabel Test of Equality of Group Means. . Hasil analisis terhadap nilai Wilk's Lambda diketahui bahwa variabel Rerurn on Equity, Earning per Share,Yield, Total Assets Turnover dan Equity Turnover, sedangkan pada periode t-1 Wilk's Lambda diketahui variabel independen yang perbedaannya signifikan di antara kedua kelompok adalah Rerurn on Equity, EBIT to Total Assets, Yield, Total Assets Turnover dan Equity Turnover.. Pada peiode t-1 dan t-2 memiliki kecenderungan yang berbeda di antara kedua kelompok (Wilk's Lambda $<9.22$ )

2. Nilai eigenvalues pada model diskriminan periode ini; periode $\mathrm{t}-2$; adalah 0,781 dengan besaran nilai canonical correlation mencapai 0.662 . Artinya, model ini mampu menjelaskan $43.82 \%(0.662 \times 0.662=0.4382)$ variasi dalam kelompok pada periode $\mathrm{t}-2$, sedangkan pada periode t-1yakni 0,556 dengan nilai canonical correlation nya adalah 0.598. Hal ini berarti bahwa model yang dihasilkan pada periode $\mathrm{t}-1$ dapat menjelaskan $35.76 \% \quad(0.598 \quad \mathrm{x}$ $0.598=0.3576)$ variasi di dalam kelompok atau dengan kata lain, angkanya mengalami penurunan sebesar $\pm 8 \%$ dibandingkan pada periode sebelumnya.

3. Melalui nilai wilk's lambda diketahui persentase variabilitas yang tak dapat dijelaskan oleh variabel independen penelitian adalah sebesar $56.1 \%(0.561)$ 
pada periode $\mathrm{t}-2$, sedangkan pada periode t-1 $p$ sebesar 0.026. Melalui tabel Wilk's Lambda di atas juga diketahui bahwa proporsi dari total variabilitas yang tidak dapat dijelaskan sebesar 0.642 atau $64.2 \%$. Model yang dihasilkan untuk periode $\mathrm{t}-2$ lebih besar $8.1 \%$ dibandingkan dengan periode $\mathrm{t}-1$.

4. Standardized Canonical Discriminant Function bisa diketahui tingkat signifikansi relatif variabel yang masuk kedalam model diskriminan periode dua tahun sebelum Return saham. Pada periode $\mathrm{t}-2$ didapat kelima variabel yang ada di dalam persamaan model (Current Assets to Total Assets, Operating Profit Margin, Return on Equity, Devidend dan Yield) dan Variabel Yield merupakan variabel prediktor terkuat dengan nilai standar kanoniknya sebesar 1.704 sehingga memiliki nilai koefesien yang besar sehingga mampu memprediksi secara akurat kecenderungan perusahaan (return positif dan return negatif). sedangkan pada t-1 terdapat empat variabel (Gross Profit Margin, EBIT to Total Assets, Yield, Current Assets to Sales)) yang ada di dalam persamaan model, EBIT to Total Assets merupakan variabel dengan tingkat signifikansi relatif tertinggi dibanding dengan variabel independen lainnya dengan nilai standar kanonikal sebesar 0.727 .

5. Group Centroids pada periode t-2 dapat dinyatakan perusahaan dengan nilai diskriminan lebih kecil atau mendekati angka -0,769 akan dikelompokkan kedalam perusahaan yang memiliki return dibawah komulatif industri sebaliknya apabila nilai diskriminannya lebih besar atau mendekati angka 0,946 dapat dikelompokkan kedalam perusahaan yang memiliki return diatas komulatif industri,sedangkan pada t-2 hasil group Centroids di dapat dinyatakan perusahaan dengan nilai diskriminan lebih kecil atau mendekati angka -0,649 akan dikelompokkan kedalam perusahaan yang memiliki return dibawah komulatif industri sebaliknya apabila nilai diskriminannya lebih besar atau mendekati angka 0,798 dapat dikelompokkan kedalam perusahaan yang memiliki return diatas komulatif industri.

6. Dari hasil pengujian klasifikasi bahwa variabel-variabel tersebut dapat membedakan kecenderungan perusahaan yang mendapatkan return positif dan return negative dan dari model diskriminan periode dua tahun sebelum return ( $\mathrm{t}-2)$ memiliki tingkat akurasi ratarata sebesar 82,2\%, sedangkan pada periode satu tahun sebelum return saham (t-1) memiliki tingkat akurasi rata-rata sebesar $79.3 \%$.

\section{KESIMPULAN}

1. Faktor-faktor rasio keuangan yang dapat membedakan antara perusahaan yang mendapatkan return positif dan negative pada periode dua tahun sebelum return saham (t-2) diketahui dari model Multiple Discriminant Analysis (MDA) bahwa variabel Current Assets to Total Assets, Operating Profit Margin, Return on Equity, Devidend dan Yield sangat signifikan di dalam membedakan kedua kelompok. Sedangkan pada periode satu tahun sebelum return ( $\mathrm{t}-1)$, berdasarkan model Multiple Discriminant Analysis (MDA) diketahui ada empat variabel yang signifikan perbedaannya di antara perusahaan yang memiliki return positif dan return negatif adalah Gross Profit Margin, EBIT to Total Assets, Yield, Current Assets to Sales.

2. Prediksi rasio keuangan terhadap return saham dengan menggunakan Multiple Discriminant Analysis (MDA) diperoleh beberapa rasio yang dapat membedakan return yang dapat disimpulkan bahwa persoalan profitabilitas dan rasio pasar adalah prediktor penting dalam meramalkan return saham. Pada periode dua tahun sebelum return, model MDA 
memiliki tingkat akurasi rata-rata sebesar $82.2 \%$. Pada periode satu tahun sebelum return saham, model MDA memiliki tingkat akurasi rata-rata sebesar $79.3 \%$ untuk meramalkan return saham.

\section{DAFTAR PUSTAKA}

Agus Indriyo, G. dan Basri. (2002). Manajemen Keuangan. Yogyakarta: BPFE.

Agus, S. (2008). Manajemen Keuangan Teori dan Aplikasi. Yogyakarta: BPFE.

Akerlof, George A. (1970). The Market for 'Lemons': Quality Uncertainty and the Market Mechanism. Quarterly Journal of Economics (The MIT Press)al, B. e. (1999). Financial Manajemen Theory and Pactice. Orlando: The Dryden Press.

Al, R. e. (2003). Corporate Finance. Mc Graw-Hill.

Allozi dan Obeidat (2016) The Relationship between the Stock Return and Financial Indicators An Empirical Study on Manufacturing Companies Listed in Amman Stock Exchange.

Alfian. (2006). Prediksi Kebangkrutan dengan Analisis Diskriminan untuk Perusahaan dalam Industri Barang Konsumsi di Indonesia.

Anderson, Eugene W. (1998), "WOM as a Consequences of Consumer Satisfaction," Journal of Service Research, Vol.1, No. 1, pp. 5-17.

Ang, Robert. (1997). Buku Pintar Pasar Modal Indonesia (The Intelligent Guide to Indonesian Capital Market). Jakarta: Mediasoft Indonesia.

Brealey, et. Al. (2007). Dasar-Dasar Manajemen Keuangan. Jakarta: Erlangga.

Brigham dan Houston. (2010). Dasar-Dasar Manajemen Keuangan (11 ed.). Jakarta: Salemba Empat.

Brigham dan Weston. (1999). Dasar-Dasar Manajemen Keuangan (9 ed.). Jakarta: Erlangga.
Chang, Su dan Chen (2006). The Relstionship between Stock Price and EPS: Evidence Based on Taiwan Panel Data.Economic Bulletin Vol 3 pp 1-12

Darmaji, T dan Fakhruddin. (2012). Pasar Modal di Indonesia (3 ed.). Jakarta: Salemba Empat

Fahmi, I. (2013). Analisa Laporan Keuangan. Bandung: Alfabeta.

— . (2012). Pengantar Pasar Modal. Bandung: Alfabeta.

— . (2014). Pengantar Manajemen Keuangan. Bandung: Alfabeta

Farkhan (2012). Pengaruh Rasio Keuangan Terhadap Return Saham Perusahaan Manufaktur di Bursa Efek Indonesia (Studi Kasus pada Perusahaan Manufaktur Sektor Food And Beverage). Jurnal Ekonomi Vol.9.No1.

Gitman, J Lawrence. (2000) Principle of Managerial Finance. Ninth Edition. RR \& Sons Company.

Gumanti, T. A. (2011). Manajemen Investasi. Bogor: Mitra Wacana Media.

Halim, A. (2005). Analisis Investasi ( 2 ed.). Jakarta: Salemba Empat.

Hanafi, M.M dan Halim, A (2009). Analisis Laporan Keuangan (4 ed.). Yogyakarta: UPP STIM YKPN.

Harahap, S. S. (2009). Analisis Kritis Atas Laporan Keuangan. Jakarta: Raja Gafindo Persada.

Lapran Keuangan. Jakarta: PT Raja Gafindo Persada.

Hartono, J. (2003). Teori Fortofolio dan Analisis Investasi (3 ed.) . Yogyakarta: BPFF-UGM.

Horne, J.C. dan Wachowicz, Jr. 2012. Primsip-prinsip Manajemen Keuangan (Fundamentals of Financial 
Management). Edisi 13 Buku 1. Jakarta: Salemba Empat

Hubbansyah, A. K. (2013). Berdasarkan Multiple Discriminant Analysis (MDA) dan Binary Logit Regresion (BLR) Terhadap Perusahaan yang Delisting pada Bursa Efek Indonesia (BEI) Periode 2008-2012.

Husnan, S. (2003). Dasar-Dasar Teori Portofolio dan Analisis Sekuritas (3 ed.). Yogyakarta: UPP AMP YKPN.

James dan John. (1995). Financial Management and Policy (8 ed.). New Delhi: Prentice Hallof India Private Limited.

Joel G, S dan Jae K, S. (1999). Kamus Istilah Akuntansi. Jakarta: PT Elek Media Komputindo.

Jogiyanto HM. (2000). Analisis dan Desain Sistem Informasi : Pendekatan Terstruktur Teori dan Praktis Aplikasi Bisnis. Andi. Yogyakarta.

Jogiyono, H. (2003). Teori Portofolio dan Analisis Investasi. Yogyakarta: BPFE.

Jumingan. 2006. Analisis Laporan Keuangan. Jakarta: PT. Bumi Aksara.

Kasmir. (2012). Analisis Laporan Keuangan. Jakarta: PT Raja Grafindo Persada.

Kasmir. (2013). Analisis Laporan Keuangan. Jakarta: Rajawali Pers.

Klecka, William R., et.al. (1975). Statistical Package for The Social Sciences Primer (SPSS). New York.

Lyn, M.F dan Aileen, O. (2008). Memahami Lapran Keuangan ( 7 ed.). Jakarta: Indeks (terjemah).

M. Freaser Lyn, A. O. (2008). Memahami Laporan Keuangan. Jakarta.

Mahmud M. Hanafi, A. H. (2009). Analisis Laporan Keuangan (1 ed.). Yogyakarta: STIE YKPN.

Mangasa, S. (2010). Pengetahuan Praktis Investasi Saham dan Dana Reksa. Jakarta: Mitra Wacana Media.

Martono dan Harjito. (2010). Manajemen Keuangan (3 ed.). Yogyakarta: Ekonisia.
Munawir. (2010). Analisa Laporan Keuangan. Yogyakarta: Liberty.

(2012). Analisis Informasi Keuangan. Yogyakarta: Liberty.

Öztürk dan Karabulut (2017) The Relationship between Earnings-toPrice, Current Ratio, Profit Margin and Return: An Empirical Analysis on Istanbul Stock Exchange.

Penman, S. H. 1992. Financial Statement Information of Earnings Change. The Accounting Review (July): 563-577.

Purnama, I. B. (2017). Pengaruh Kinerja Keuangan dan Variabel Makro Ekonomi Terdahdap Harga Saham Perusahaan Pertambangan.

Raharjo, S. (2006). Kiat Membangun Aset Kekayaan. In Panduan Investasi Saham. Jakarta: PT Elek Media Komputindo.

Riyanto, B. (2008). Dasar-Dasar Pembelanjaan Perusahaan . Yogyakarta: GPEE.

Ross et. Al. (2003). Corporate Finance. 5th. New York : McGraw-Hill

(2010). Fundamental of Corporate $(9$ ed). New York : McGrawHill

Samsul, M. (2016). Pasar Modal dan Manajemen Portofolio (2 ed.). Jakarta: Erlangga.

Sapto, R. (2006). Kiat Membangun Aset Kekayaan. Jakarta: Elex Media Komputindo.

Sawir, A. (2009). Analisa Kinerja Keuangan dan Perencanaan Keuangan Perusahaan. Jakarta: PT Gramedia Pustaka Utama.

Scott, W. R. (2000). Financial Accounting Theory. USA: Prenitice Hall.

Siamatupang, M. (2010). Pengetahuan Praktis Investasi Saham dan Dana Reksa. Jakarta: Mitra Wacana Media.

Sugiyono. (2015). Metode Penelitian Pendidikan (Pendekatan Kuantitatif, Kualitatif dan R\&D). Banung : Alfabeta.

- (2017), Metode Penelitian Kuantitatif. Kualitatif dan R\&D. Bandung : Alfabeta. 
Sunariyah. (2006). Manajemen Keuangan: Teori, Konsep \& Aplikasi. Yogyakarta: UPP STIM YKPN.

Sutrisno. (2012). Manajemen Keuangan Teori. Yogyakarta: Ekonisia.

Tandelin, E. (2010). Analisis Investasi dan Manajemen Fortofolio. Yogyakarta: BPFE Yogyakarta.

Tatham, R.L. \& Black, W.C. (1998). Multivariate Data Analysis. 5th edition. Upper Saddle River: Prentice Hall.
Teapon. (2009), Pengaruh Debt to Ratio (ROA), Return on Equity (ROE), dan Price to Book (PBV) Terhadap Perusahaan Manufaktur di Bursa Efek Jakarta.

Warsidi dan Pramuka. (2000). Evaluasi Kegunaan Rasio Keuangan dalam Memprediksi Perubahan Laba di Masa yang aka Datang: Suatu Empiris pada Perusahaan yang Terdaftar di BEJ. Jurnal Akuntansi Manajemen dan Ekonomi Vol.2.No1. 